\title{
23. \\ O PRIJATELJSTVU I JOŠ PONEČEMU
}

\section{Iva Tešić}

UDK: 821.163.42-6Desnica, V.(044)

Izvorni znanstveni članak

Sažetak: Prepiska Vladana Desnice, njegovog sina Uroša i ćerke Nataše Desnice, sa Draganom M. Jeremićem predstavlja svedočanstvo o prijateljstvu između dva književnika, ali ujedno otkriva i Jeremićevu ulogu u recepciji Desničinog stvaralaštva u Srbiji. Zapravo, pisma su bila podsticaj da podsetimo na položaj u kom se Desnica, kao pisac dvojake pripadnosti, nalazio i u hrvatskoj i u srpskoj književnosti. Da bismo u potpunosti razumeli poziciju ovog stvaraoca unutar hrvatsko-srpskog kulturnog prostora, neophodno je ukazati na važnost konteksta u kome je živeo i stvarao. U toj nameri, jedan deo ovog rada posvećen je upravo prisećanju na takozvane „spoljašnje“ činioce koji su, očigledno, imali presudnu ulogu za književnu delatnost Vladana Desnice. Mogli bismo čak reći da su baš ti neumetnički i neknjiževni faktori umnogome odredili njegovu književnu sudbinu. Pokazujući dosledan otpor u podvrgavanju nametnutim obrascima i odbijajući da se izjasni „čiji je“, Desnica je viđen kao opasnost i pretnja za dalji razvoj književnosti, odnosno prepoznat kao neko koga je potrebno ukloniti sa scene. Tadašnji zastupnici i branitelji proklamovane „istine“ pobrinuće se da bude odstranjen iz kulturne javnosti. $\mathrm{O}$ ambijentu u kom je radio, brojnosti napada kojima je bio izložen, kao i zamerkama koje mu je kritika upućivala (ispitivanje moralne ispravnosti junaka, insistiranje na preciznom određenju vremena i mesta radnje, sumnjičenje za upotrebu pojedinih reči...) najbolje govori Desničina polemička zaostavština. Između ostalog, i u prepisci sa Draganom M. Jeremićem otkrivamo izvesne činjenice koje potvrđuju opšte (ne)raspoloženje koje je tokom 50-ih i 60-ih godina prema Desnici vladalo. Pomenuli bismo da, osim što upotpunjuju sliku o tretmanu jednog od najznamenitijih jugoslovenskih pisaca, pisma daju povoda i da se osvrnemo na pojam interkulturalnosti. Podsetićemo - bavljenje identitetima danas postaje takoreći stvar mode. Svakodnevno smo preplavljeni diskusijama (utemeljenim u mnogobrojnim teorijskim pristupima) o raznim oblicima identiteta. S tim u vezi, sve je popularniji i frekventniji pojam interkulturalnost, kojim se ukazuje na različite oblike identitetskih relacija. Ipak, u radu se izražava sumnja u opravdanost korišćenja pomenutog pojma u slučaju promatranja stvaralaštva Vladana Desnice. Imajući $\mathrm{u}$ vidu da je konstruisanje različitih oblika identiteta uvek ideološki obojeno, čini nam se neprikladnom zamisao o korišćenju današnjih okvira /aršina/ terminologije prilikom izučavanja razdoblja koje nije poznavalo takvu „istraživačku“ aparaturu.

Ključne reči: Vladan Desnica, Dragan M. Jeremić, prepiska, identitet, interkulturalizam dina XX veka (uključujući i pisma koja su Nataša i Uroš Desnica upućivali Jeremiću) imaju višestruki značaj. Pre svega, svedoče o intenzivnoj i prijateljskoj komunikaciji 
vođenoj između dva intelektualca, dok, sa druge strane, one važnije za književnoistorijsku perspektivu, ukazuju na položaj u kome se nalazio jedan od najznačajnijih stvaralaca u okviru jugoslovenskih književnosti XX veka. Prepiska predstavlja podsticaj da se osvetli figura Vladana Desnice, ali, istovremeno, dobra je prilika da podsetimo na važne detalje koji su odredili njegovu književnu sudbinu.

Nakon objavljivanja prvog romana Zimsko ljetovanje (1950.), usledila je lavina negativnih ocena, napada, potcenjivanja, što je doprinelo obeležavanju Desnice kao ideološki nepravovernog i nepodobnog. Optužbe su započete prikazom Jože Horvata, koji je, prema Desničinim rečima, „bez pretjeranog udubljivanja u materiju, pokušao da knjigu likvidira sa

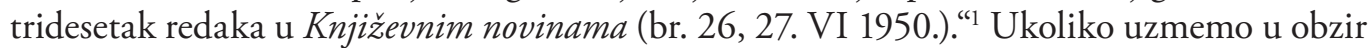
način na koji je knjiga kvalifikovana, kao i (tobožnja) kritičarska načela koja su primenjena, zapazićemo priličnu količinu malicioznosti. Desničinoj prozi zameran je nedostatak realističnosti, manjak „perspektive“ kod junaka, čak je istaknuto da je delo lišeno „prave ljudske vrednosti“: „Ali njegova proza nema ni pozitivnog lika! (...) Ali njegova proza nema nijednog svijetlog momenta... (...) A mnogo je u ovoj knjizi teških stvari rečeno o čovjeku, i posebno o našem selu. “2 Neobična okolnost je da se u to vreme čekalo na recenziju i po nekoliko meseci, a za Zimsko ljetovanje je bilo potrebno svega nekoliko dana. Na taj podatak ukazuje Desnica u odgovoru na napade („O jednom gradu i o jednoj knjizi“), koje je objavio u Zadarskoj reviji tek 1954., četiri godine nakon pojavljivanja negativnih kritika. U istom tekstu Desnica pominje da se u međuvremenu i strana kritika izjasnila o romanu, svrstavajući ga među najznačajnija prozna ostvarenja svetske književnosti.

Mada je druga Desničina knjiga Olupine na suncu (1952.) nagrađena Prvomajskom nagradom Saveza književnika Jugoslavije, glasovi kritike bili su dalje podeljeni, a nagrađivanje je obeleženo svojevrsnim skandalom - jedan od članova žirija javno se ogradio od odluke da Desnici pripadne nagrada, smatrajući je pogrešnom i promašenom. Uz Petra Šegedina i Jura Kaštelana, Ivan Dončević je, kao treći član komisije, svoj istup javnosti obrazložio na sledeći način:

Kako sam naime duboko uvjeren, da je nagrađivanje V. Desnice Prvomajskom nagradom Saveza književnika Jugoslavije (...) pogrešno i promašeno, to se na ovaj način ograđujem od toga da sam i na posredan način - kao član komisije za Hrvatsku - pri donošenju takve odluke učestvovao. ${ }^{3}$

Kao prevlađujuće odlike Olupina na suncu istaknuti su pesimizam i naturalizam, tom prilikom je ismevana svaka pohvala na račun Desničinog stvaralaštva, dovođena je u pitanje njegova, često isticana, erudicija, a prisutnost takozvane beogradske i zagrebačke stilske varijante dala je povoda da se komentarišu i jezička „ogrešenja“: „Desnica piše ijekavicom, ali donekle lavira između shvaćanja i običaja zagrebačkog i beogradskog književnog kru-

1 Vladan Desnica, „O jednom gradu i o jednoj knjizi“, Hotimično iskustvo - diskurzivna proza Vladana Desnice, knj. 1. (prir. Dušan Marinković), Zagreb 2006., 133.

2 Marin Franičević, „Zimsko ljetovanje Vladana Desnice“, u: V. Desnica, Progutane polemike (prir. Jovan Radulović), Beograd 2001., 115.

3 Ivan Dončević, „Izjava Ivana Dončevića povodom prvomajskih nagrada Saveza književnika Jugoslavije 1953.“, u: V. Desnica, Progutane polemike, 142.

4 M. Lj. S., „Za ozbiljniju kritiku. Primjedbe uz jednu 'kritiku'“, u: V. Desnica, Progutane polemike, 139. 
ga.“4 Omalovažavanje je bilo nezaobilazno i u slučajevima kada su zapažane vrednosti u Desničinom radu. Jedan nedobronamerni arbitar, isprovociran pohvalnom ocenom koju je Mirko Žeželj objavio u NIN-u, apelovao je na „ozbiljniju“ kritiku:

A Desnica je pisac značajne nadarenosti i nekih zanimljivih ostvarenja, ma kako se sve to sporo i teško rađalo; no još uvijek ne i siguran, definitivno izgrađen (što najbolje svjedoči ova knjiga kao plod 20-godišnjeg nastojanja), pa je neprikladno istupati nekritički, povlađivati mu i tamo, gdje ne treba, umjesto da mu se kritičkim opaskama pomogne... 5

U vezi sa zbirkom Olupine na suncu treba pomenuti i važnost javne diskusije koja je održana 1952. u Društvu književnika Hrvatske. Tema je bio referat Miroslava Krleže sa III Kongresa književnika Jugoslavije, koji se ticao pitanja slobode umetničkog stvaranja. Tom prilikom Vjekoslav Kaleb je ukazao na negativne strane „preterane“ umetničke slobode, navodeći kao primer prikaz Desničine zbirke pripovedaka, čije objavljivanje, kako priznaje, nije uspeo da spreči. Povodom toga, Desnica će u tekstu „Vjekoslav Kaleb i idealizam - sitan prilog našoj kulturnoj istoriji“6 pomenuti neobjašnjivu „slučajnost“ koja je pratila zbirku Olupine na suncu. Naime, od svih Matičinih knjiga jedino Olupine na suncu nisu registrovane u Bibliografskom biltenu. Kada je nadležnima ukazao na propust, dobio je odgovor da je nemoguće učiniti naknadne ispravke.

Osim toga, člankak pod naslovom „Zapisi o umjetnosti. (Iskustva i refleksije)“, objavljivan u nastavcima 1952. u časopisu Krugovi, izazvao je žestok gnev književnih sudija, koji su u Desnici videli pisca s kojim se treba obračunati. Pored književnih i jezičkih zamerki, u ovom slučaju očigledno manje bitnih, Desnica je shvaćen kao ideološki prestupnik čije je ogrešenje neoprostivo. Najsporniji deo „Zapisa“ odnosio se na predlog o uvođenju „primenjene književnosti“:

Analogija s likovnim umjetnostima porađa mi spasonosnu ideju: kao što su se tamo odijelili i dobili svoje mjesto i položaj ogranci koji imaju praktične primjene, zašto da se to isto ne provede i na području književnosti? (...) Prestala bi trvenja i natezanja, sve bi praktičke, programatističke, utilitarne i slične tendencije našle svoje zadovoljenje...?

Desnica je osuđen zato što nastupa kao pater familias literatorum, koji pokušava da „zabije nož u leđa toj književnosti, da je diskvalifikuje u očima omladine“. ${ }^{8}$ Svojim antimaterijalističkim i idealističkim „burgijama od uma“, kako je govorio Dončević, Desnica je duboko uzdrmao postulate socijalističkog koncepta, zbog čega je ideja o primenjenoj književnosti ocenjena kao „bezočno izazovna, zlobna i cinična“. 9 Desničino oglušivanje o istinu, u kojoj je angažovana literatura videla neprolazni umetnički smisao, ipak je bila najprovokativnija i, kako su ondašnji branitelji i zastupnici „pravih“ vrednosti smatrali, zavređivalo je apsolutnu diskvalifikaciju autora:

Isto, 137.

V. Desnica, „Vjekoslav Kaleb i idealizam. Sitan prilog našoj kulturnoj historiji“, Hotimično iskustvo, knj. $1 ., 394$.

Isti, „Zapisi o umjetnosti (Iskustva i refleksije)“, Hotimično iskustvo, knj. 1., 72.

$8 \quad$ N. ST., „Ecce homo“, u: V. Desnica, Progutane polemike, 44.

9 I. Dončević, „Kukavičja jaja Vladana Desnice ili kako se odgaja mladež“, u: V. DesnicA, Progutane polemike, 53. 
Dokazati, da beletristički tekstovi Vladana Desnice s našim vremenom, s našom stvarnošću, s našim ljudima, s onom istinom koja je uvijek bila pa i danas treba da bude glavni smisao umjetnosti, nemaju nikakve ili gotovo nikakve veze, mislim, da bi bilo sasvim jednostavno. ${ }^{10}$

Jože Horvat je izneo sličan prigovor, uz upozorenje da „put na koji Vladan Desnica poziva mlađe pisce vodi neminovno u sukob s progresivnim snagama u društvu i istinskom književnošću“. ${ }^{11} \mathrm{Uz}$,izlive žuči“ koje su razni pravoverni književni poslenici usmeravali na njega, Desnici je (zbog „tih ciglih desetak redaka (...) napisa“) bio ugrožen opstanak na javnoj sceni, čak i dalje bavljenje književnim radom, o čemu svedoče sledeće reči:

Posljedica te hajke bila je da su se preda mnom zatvorila vrata svih redakcija u sredini u kojoj živim i u kojoj radim - čak i onih koje su me dotad pozivale na saradnju - i da su ta vrata zadugo ostala preda mnom zatvorena. (...) Znanci i kolege počeli su me čak i u društvenom ophođenju izbjegavati. (...) Za mene je važno, da mi je u toj zgodi uskraćena svaka mogućnost da bilo gdje i bilo kako odgovorim na te napade, da se pokušam od njih odbraniti. (...) Odgovore i pokušaje objašnjenja u bilo kom obliku koje sam napisao na sve te napadaje, uzaludno sam nudio svim redakcijama koje su te napadaje objavile, pa i mnogim drugim. I tako, nije mi preostalo ništa drugo nego da ih spremim u fascikli koja nosi naziv Progutane polemike. ${ }^{12}$

Želja da javnosti pruži celovit uvid u situaciju u kojoj se nalazio nije ostvarena za života, pa su polemike zaista ostale progutane u vremenu, čekajući nekoliko decenija da ugledaju svetlost dana. Tekstove objedinjene pod navedenim naslovom sabrao je i objavio Jovan Radulović 2001. godine, a možemo ih pronaći i u knjizi Hotimično iskustvo - diskurzivna proza Vladana Desnice (knjiga prva), čiji je priređivač Dušan Marinković.

Neprilike kojima je Desnica bio izložen već od svog prvog stupanja na književnu scenu nakon rata bile su do te mere nesnosne da su dovele u pitanje nastavak bavljenja književnim radom. U pismima upućenim Veljku Petroviću, Vladan Desnica je o tom periodu ovako govorio:

Zavisiti će od praktičnih prilika i uslova koliko ću još moći da istrajem na čisto književnom planu. (...) Zacijelo su do vas doprli odjeci nedostojne i montirane kampanje koja se proti meni vodi, gotovo bez predaha, već kakvih 6-7 godina - od prvog dana kad sam se „literarno pojavio“ poslije rata. Po samim tim odjecima mogli ste zaključiti da ovdje meni „ne cvatu ruže“ ni u moralnom ni u materijalnom pogledu. Neću da upadam u patetički ton i da Vam natenane iznosim sve načine na koje sam maltretiran, ćulan, unižavan, prešućivan, onemogućavan. (...) Ukratko, sad je stanje dotjeralo dotle da sam gotovo sasvim paraliziran u mom radu i lišen mogućnosti da ma šta ovdje objavljujem. ${ }^{13}$

Usled takvog „spleta“ okolnosti Desnica pokušava da se preorijentiše i stvori prostor za rad u Srbiji. Tražeći način za ostvarivanje te zamisli, obraća se viđenijim kulturnim radnicima, očekujući sugestije, razumevanje, pomoć.

10 Isto, 48.

11 Joža Horvat, „Margine“", u: V. Desnica, Progutane polemike, 41.

12 V. Desnica, „Nesporazumak oko 'Primjenjene književnosti'. Mali prilog našoj kulturnoj historiji“, u: Isti, Progutane polemike, 58-59.

13 Isti, „Tri pisma Veljku Petroviću“, Književna istorija, XLVII/2015., br. 156, 169-175. 
Međutim, ni u Srbiji neće naići na blagonaklonost i naročito prijateljski odnos. Čak naprotiv - ponovo biva izložen beskrupuloznim podmetanjima. Načini na koje je odstranjivan iz konkurencije za dodelu književnih nagrada dali su povoda da se Desnica požali Aleksandru Vuču, tadašnjem sekretaru Saveza književnika Jugoslavije:

Prilikom zasjedanja, pretresanja i odlučivanja o raznim nagradama, s čudnom upornošću servira se činjenična dezinformacija koja me sili da iziđem iz rezerve i da ti uputim ovih nekoliko riječi nužnog objašnjenja. Mojoj najnovijoj knjizi Tu, odmah pored nas prikrpljena je etiketa „retrospektivnosti“, a ispod ruke protura se da je ona, pod drugim naslovom ili u nešto drugačijem sastavu, već jednom nagrađena. (...) Vjerujem da čitav moj habitus i stil postupanja dovoljno svjedoče koliko mi je strano svako laktašenje, ali čovjeka čisto revoltira ovako očito falsifikovanje golih činjeničkih podataka. (...) Knjiga (...) može da bude u meritorumu pronađena nedostojna nagrade koliko god da se to hoće i želi, ali ne treba dozvoliti da se operira formalnim smicalicama koje se osnivaju na flagrantnim dezinformacijama i očitom izvrtanju fakata. Ističem, niukoliko ne želim uticati na sam meritorni sud o mojoj knjizi. Bio bih veoma zadovoljan kada bih sigurno znao da su je pročitali oni koji o njoj imaju da odluče. ${ }^{14}$

U prilog ravnodušnosti prema poziciji Vladana Desnice govori još jedan podatak. Aleksandar Tišma u svojoj knjizi Pre mita prilaže pismo koje mu je Desnica uputio 1952. godine, objavljujući ga pod naslovom „Jedno pismo Vladana Desnice i njegov povod“. U propratnom tekstu Tišma priznaje sledeće:

Na pismo Vladana Desnice, upućeno meni 23. marta 1952, upozorio me je nedavno Dobrivoj Nađvinski, koji je na njega naišao tokom rada u Rukopisnom odeljenju Matice srpske. Ja sam na to pismo potpuno zaboravio: verovatno sam ga, uskoro po prijemu, predao Rukopisnom odeljenju, shvativši da je važno da se sačuva. Ali povoda koji mi je to pismo doneo dobro se sećam. ${ }^{15}$

Odgovarajući na Tišmine nedoumice oko pisanja prikaza o zbirci Olupine na suncu, Desnica pravi kratak osvrt na ustaljenu kritičarsku praksu, ukazujući na šabloniziranost i nedovoljno razumevanje umetničkog instinkta, koji za njega predstavlja rukovodeći stvaralački princip. S tim u vezi, prkosno će odbrusiti: „Svakako (...) moram da priznam: ako griješim, pogreška je tim teža što je svjesna i hotimična." ${ }^{16}$

U pomenutom pismu otkrivamo još jedan važan detalj. Naime, Desnica moli Tišmu da ponovo pažljivo pročita knjigu ukoliko želi da piše o njoj. Svoju sugestiju objašnjava jednom banalnošću koja mu se dogodila:

Možda mi se to čini potrebnim i samo zato što ja imam običaj da svaku stvar, pa i dječju pričicu iz Pionira, ako je već čitam, pročitam po dva, po tri puta, i to veoma pažljivo, pa pomišljam da je i drugom to možda korisno. Na tu me preporuku navodi i jedna mala nezgoda koja mi se nekidan desila s jednim ovdašnjim mlađim recenzentom (...) naime, u svojoj, uostalom veoma povoljnoj, recenziji pobrkao je, očevidno zbog prebrzog i letimič-

14 Radovan Popović, „Preplitanja proleća i smrti. Fragmenti za biografiju Vladana Desnice“, Književni magazin, godina V/2005. (avgust), br. 50, 58-61.

15 Aleksandar Tišma, „Jedno pismo Vladana Desnice i njegov povod“, Pre mita, Banjaluka 1989., 106.

16 V. Desnica, „Pismo Vladana Desnice Aleksandru Tišmi“, Hotimično iskustvo, knj. 1., 85. 
nog čitanja, dva sasvim različita lika iz dvije razne pripovijetke (...) tako da se nikako ne razumije o kojoj od te dvije stvari govori. ${ }^{17}$

Za razumevanje pozicije Vladana Desnice u hrvatsko-srpskom kulturnom prostoru neophodno je bilo podsetiti na kontekst, zapravo na izvesne činjenice koje svedoče o opštem (ne)raspoloženju koje je prema njemu vladalo 50-ih i 60-ih godina.

Nedobrodošao u sredini u kojoj je živeo i radio, skrajnut i površno tumačen, nipodaštavan i osujećivan, Desnica je bio primoran da svoj rad usmeri ka srpskim časopisima i izdavačima. Nuđenje knjiga, predlozi o mogućim reizdanjima, davanje dozvole za jezičke i ortografske redakcije izvornog teksta, čak pominjanje ideje da se i „fizički“ preseli u sredinu kojoj, kako je govorio, „prirodno spada“, ${ }^{18}$ ukazivali su na Desničinu jasnu želju da bude deo srpske književnosti.

Rado bih se preselio u Beograd ne samo svojim radom nego i čisto „fizičeski“, kad u današnjim prilikama i s mojom brojnom familijom ne bi bio grdan problem i seljenje iz ulice u ulicu a kamoli iz jednog grada u drugi. I tako, bar zasad, moram da se zadovoljim ovakvim „duhovnim preseljenjem“. 19

Ipak, sticaj okolnosti učinio je da pisac bude neshvaćen i da njegove molbe, upućivane uticajnim srpskim književnicima, ostanu su bez odjeka.

Iz tog razloga, prepiska sa Draganom M. Jeremićem predstavlja segment koji upotpunjuje sliku o tretmanu ovog stvaraoca. Jeremić je značajan ne samo kao jedan od, u ono vreme malobrojnih, poštovalaca Desničinog dela, već i kao osvedočeni prijatelj Desničine porodice. Relacija između Desnice i Jeremića nije bila samo poslovnog karaktera. U prilog tome govori njihova prepiska, koja nije usmerena isključivo na književne teme, niti je odlikuje formalni ton. Dvojica književnika razmenjivala su novogodišnje čestitke, Desnica se javljao sa letovanja, obaveštavao o svojim privremenim odlascima iz Zadra ne bi li blagovremeno i na pravu adresu dobio eventualno pismo od prijatelja, zatim najavljivao dolaske u Beograd, pozivao kod sebe u Zadar, radovao se ponovnim susretima...

U vreme trajanja prepiske Jeremić se nalazio na uglednim položajima: radio je na Filozofskom fakultetu u Beogradu, bio glavni urednik Savremenika, predsednik Saveza književnika Jugoslavije i predsednik Srpskog filozofskog društva.

Ukoliko uporedimo Desničino pismo upućeno oktobra 1962. Draganu M. Jeremiću sa pismom iz 1953., adresiranog Veljku Petroviću, zapazićemo činjenicu koja svedoči o decenijskom izopštavanju Vladana Desnice: godine 1953. godine Desnica podseća Petrovića da su u Beogradu štampane knjige hrvatskih autora, što mu uliva nadu da će u jednom momentu i njemu biti pružena prilika:

(...) pomišljam da bih eventualno i ja mogao da dođem na red, bilo u izdanjima SKZ, Prosvete, Nopoka, ili ma gdje drugo. Htio bih Vas samo zamoliti da se, do prilike, usput raspitate postoji li objektivna mogućnost i dobra volja da se tamo izda kakva moja stvar (...). ${ }^{20}$

\footnotetext{
17 Isto, 88.

18 Isti, „Tri pisma Veljku Petroviću“, Književna istorija, XLVII/2015., br. 156, 177.

19 Isto, 173.

20 Isto, 173-174.
} 
(...) Lijepo Vas molim da me uputite kome da se obratim, jer ja nemam nikakvih veza ni poznanstava s ljudima i ustanovama. Ukoliko biste Vi, koji imate bližeg kontakta i bolji pregled nad tamošnjom izdavačkom delatnošću, o tome govorili beogradskoj Prosveti ili drugom kojem izdavačkom preduzeću, bio bih Vam blagodan. ${ }^{21}$

Tragična je okolnost da je Desnica nakon 9 godina u nepromenjenom status - očekujući da se roman Proljeća Ivana Galeba pojavi u dogovorenom roku, po ko zna koji put doživljava neprijatnost:

Ta stalno je govoreno i potvrđivano da će moja knjiga izići u novembru, a sad me eto izboksiraše napolje! To me je vrlo neprijatno iznenadilo, i mnogo mi pomrsilo planove. Lijepo Vas molim (...) nastojte da se mojoj knjizi vrati red koji joj je bio dan te da iziđe u novembarskoj seriji. ${ }^{22}$

Dragan M. Jeremić nije ostajao nem na Desničine žalbe, shvatajući nelagodnost njegove pozicije kao posledicu nespremnosti sredine za takvu vrstu umetničke individualnosti:

U vreme kada je Vladan Desnica objavio svoju prvu knjigu, roman Zimsko ljetovanje (1950), u našoj književnosti je bila prošla konjunktura pisanja po receptu koji se zvao socijalistički realizam, ali ovaj recept je bio odbačen više teorijski nego praktično, zato je prvo Desničino delo naišlo na neka nerazumevanja kod pisaca koji nisu bili spremni da se susretnu s jednim novim vidom književnog stvaranja. ${ }^{23}$

Jeremić je u Desnici video stvaraoca kojem u okviru jugoslovenskih književnosti pripada isto ono mesto koje u Francuskoj ima Prust, u Engleskoj Haksli, odnosno Man u Nemačkoj. Tvrdio je da se veličina ovog pisca ne iscrpljuje u spisateljskom majstorstvu, zbog čega ga je svrstavao među večite umetnike, čija vrednost ne prolazi tempom kojim prolaze razni književni pravci i škole. Jeremić je ukazivao na jezičko majstorstvo, sposobnost zapažanja, sklad i jedinstvo Desničine ličnosti i dela, u kojima je video odraz neobičnog ukrštaja suprotnosti - lirskog i idejnog, emotivnog i razumskog, stvaralačkog i iskustvenog.

Posebno treba istaći Jeremićeve zasluge za objavljivanje novih izdanja Proljeća Ivana Galeba 1962. i 1963. godine u Izdavačkim preduzećima „Branko Đonović“ i „Savremenoj administraciji“, odnosno izdavanje drame "Ljestve Jakovljeve” u časopisu Savremenik 1961.

Jeremićev značaj za afirmaciju i recepciju Desničinog stvaralaštva je nesumnjiv. Čak i nakon piščeve smrti, članovi Desničine porodice održavaće komunikaciju sa Jeremićem. U obraćanju Jeremiću nakon očeve smrti, Nataša Desnica piše: „Čudno nam je što ste mogli i pomisliti da Uroš ili bilo tko od nas ne zna za Vas, jednog od rijetkih vjernih prijatelja našeg oca, koji Vas je volio i cijenio. "24 I Uroš i Nataša se zahvaljuju na vremenu koje Jeremić posvećuje komunikaciji sa njima, kao i na želji da sačuva sećanje na njihovog oca. Osim što traže savete za pregovaranje sa izdavačima, kao i pomoć u vezi sa književnom zaostavštinom, pokazuju i otvorenost i spremnost da sarađuju i pomognu koliko je to u njihovoj moći. Jeremićeva zamisao da izda monografiju o Vladanu Desnici nije ostvarena, ali je reakcija

\footnotetext{
Isto, 172 .

22 Arhiv Srpske akademije nauka i umetnosti (dalje: SANU), neobrađena građa.

23 Dragan M. Jeremić, Prsti nevernog Tome, Beograd 1965., 152.

24 Arhiv SANU, neobrađena građa.
} 
piščeve porodice dokaz o apsolutnom poverenju prema tom naumu: „Neobično nam je drago (...) jer smo uvjereni da nitko ne bi to bolje od Vas uradio. (...) Do sada su mnogi pisali sa izrazitim nedostatkom sluha za njegove vrednote, čak i kad je to bilo dobronamjerno." ${ }^{25}$

Iz pisma Desničine ćerke saznajemo da je Jeremićev govor na ispraćaju posmrtnih ostataka iz Zagreba u Islam Grčki posebno zapažen: „Moramo Vam reći da je Vaš govor napravio veliki utisak, i da je po mišljenju ne samo nas bio daleko najvredniji od svih koji su održani u Zagrebu i Islamu. “26 Tom prilikom Jeremić je istakao: „Opraštajući se od njega, ne treba reći: umro je, nego: preselio se iz života u slavu. ${ }^{\text {227 }}$

Skoro pola veka od Desničine smrti promenjeni su okviri tumačenja i pristupa njegovom delu. Sticajem neknjiževnih okolnosti, savremenom dobu postaju svojstveni izvesni pojmovi koji su u, ne tako dalekoj, prošlosti bili nepoznanica. Premda govoriti o Desničinom delu kroz prizmu interkulturnih relacija u hrvatsko-srpskom kontekstu stvara utisak izvesnog učitavanja ili dopisivanja, vredi ih ispitati. Bez obzira na skorašnje događaje, koji su umnogome izmenili načine interpretacije, ne sme se prenebregnuti činjenica da je Vladan Desnica umetnik koji je obeležio period u kom se srpsko-hrvatske veze nisu posmatrale sa interkulturalnog aspekta - tada su u opticaju bili drugi pojmovi. Ovde, pre svega, mislimo na jugoslovenstvo kao nadnacionalni koncept (čije je ishodište još u devetnaestovekovnom snu o osnivanju zajedničke države Južnih Slovena). U svoje vreme, ideologija jugoslovenstva prožimala je svaki oblik delatnosti. Podsetićemo kako se prema pitanju književnosti u to vreme odnosilo - u knjizi Antuna Barca Jugoslavenska književnost pronalazimo sledeću definiciju: „Izraz 'jugoslavenska književnost' zajednički je naziv za literature Srba, Hrvata, Slovenaca i Makedonaca, okupljenih u Socijalističkoj Federativnoj Republici Jugoslaviji. ${ }^{28}$ Dok je nekada insistirano na zajedništvu, danas se podvlače identitetske distinkcije i govori se o interkulturalizmu kao procesu u kome sudeluju različiti kulturni identiteti. Mada je Barčev pregled jugoslovenskih književnosti prikazivao pojedine književnosti zasebno, bilo je moguće zamisliti određenu jugoslovensku sintezu. Terminom interkulturalizam označavaju se interakcije između kultura, pri čemu se podrazumevaju samosvest i neophodno uvažavanje drugoga. U Leksikonu savremene kulture čitamo: „Interkulturalna kompetencija predstavlja sposobnost da se stvori međuprostor koji, putem otvorenosti, empatije i tolerancije, omogućuje dijalog između ljudi različite kulture. ${ }^{\text {(29 }}$

Iako verujemo da interkulturni pristup ne previđa određeni kulturni međuprostor, ovom prilikom možemo se zapitati jesu li identitetski parametri fiksirane kategorije, čija je vrednost nepromenljiva na dijahronoj ravni, ili se aršini za uspostavljanje kriterijuma menjaju shodno ideološko-političkim konstruktima. Naime, pojam interkulturalizam pretpostavlja i problematizovanje identitetskih odrednica, koje, kao što je očigledno, nastaju i nestaju shodno preovlađujućoj ideološkoj podlozi.

25 Isto.

26 Isto.

27 D. M. Jeremić, „Za očovječenje čovjeka - govor održan prilikom ispraćaja posmrtnih ostataka Vladana Desnice“, Telegram (Zagreb), VIII, br. 358, 10. 3. 1967., 10.

28 Antun Barac, Jugoslavenska književnost, Zagreb 1963., 5.

29 „Interkulturalizam“, Leksikon savremene kulture. Teme i teorije, oblici i institucije od 1945. do danas (prir. Ralf Šnel), Beograd 2008., 258. 
Sagledavanju činjenica vezanih za jugoslovenski kontekst pristupa se sa drugačijih polazišta, što je uslovljeno društveno-političkim činiocima. Međutim, ukoliko se danas bavimo istraživanjem takozvanog postjugoslovenskog tla, opravdano je da govorimo sa aspekta interkulturalnosti. Štaviše, proučavanja orijentisana na postjugoslovenski fenomen postaju neka vrsta trenda i istraživačke „egzotike“, imajući u vidu specifičnost podneblja i konkretne prilike koje su prouzrokovale raskol i neprijateljstvo.

Postjugoslovenski pejzaž pruža jedinstvenu situaciju. (...) Radi se o kako postsocijalističkom, tako i o postkonfliktnom regionu, koji je (...) bio predmet višestrukih procesa dezintegracija, uspešnih i neuspešnih procesa otcepljenja i velikog broja različitih unutrašnjopolitičkih i teritorijalnih angažmana. ${ }^{30}$

Čini se da su upravo ideološki zahtevi najpretežniji, što za posledicu ima nasilno uklapanje predmeta istraživanja u kategorije koje su u određenom trenutku validne. Pravilo važi i u književnosti, pa tako:

Govoriti o identitetu savremene književnosti - to, naravno, danas takođe znači ne govoriti više o književnosti kao području samodovoljnosti i autarhičnosti, o književnosti „kao takvoj", nego u isti mah govoriti i o kulturi, politici, ideologiji, istoriografiji, sociologiji, antropologiji, informatici, demografiji, ekologiji, bioetici... ${ }^{31}$

Podređivanje važećim standardima i usklađivanje s aktualnom aparaturom i terminologijom postaje neizbežno. Dakle, promišljanje činjenica iz prošlosti u sadašnjem momentu nužno dobija nove dimenzije. U slučaju Vladana Desnice, situacija je istovetna. Baveći se stvaralaštvom ovoga pisca danas, u vidu imamo trenutne relacije između Srbije i Hrvatske, odnosno perspektivu koja, u kontekstu u kom je Desnica živeo i stvarao, nije bila poznata. Priča o interkulturalizmu povlači i priču o identitetu, što „možda više od svega i pre svega znači razmišljati i pisati, konceptualizovati i realizovati nešto što zapravo počiva na 'brisanom prostoru' između stvarnosti i zamišljanja, između činjenica i njihovog kreiranja i/ili tumačenja, između (de)konstrukcije i (re)konstrukcije naizgled očevidnoga i naoko prividnoga" 32

O Desničinom interkulturalizmu možda je opravdanije govoriti imajući u vidu korelacije njegovog dela s evropskim književnostima. Da podsetimo - Desnica je sebe smatrao jugoslovenskim piscem. Iako je ta kvalifikacija danas prilično nepopularna, i sam pojam dosta neodređen, ne smemo zaboraviti da je ovaj pisac insistirao upravo na takvome određenju, izbegavajući da se izjasni na drugačiji način, čak ne pojašnjavajući šta tačno znači biti $u$ isti mah i hrvatskim i srpskim:

Kad sam rekao da se smatram jugoslovenskim piscem, time sam mislio: $\mathrm{u}$ isti mah i hrvatskim i srpskim. (...) strogo alternativno „hrvatski ili srpski“ u stvari znači „ako hrvatski - onda ne srpski“, i obrnuto. A to je upravo ono što stoji u suprotnosti s mojim stavom. ${ }^{33}$

\footnotetext{
30 Igor ŠTıKs i Džon Šo, „Državljanstvo u novim državama Jugoistočne Evrope“, u: Državljani i državljanstvo (prir. Džon Šo i Igor Štiks), Beograd 2012., 11.

31 Tihomir BRAJOvić, „Nekoliko reči o komparativnom identitetu savremene srpske književnosti“, MSC, 40/2001., br. $2,327-328$

32 Isto, 331 .

33 Dušan Marinković, „Biografija Vladana Desnice“, u: V. Desnica, Hotimično iskustvo, knj. 1., 247.
} 
Ispostavlja se da je Desničina istrajnost u sleđenju sopstvenih ubeđenja ipak bila svrsishodna. Doslednost je, podrazumeva se, imala skupu cenu, o čemu svedoče mnogobrojni posthumno objavljeni polemički tekstovi. Odricanje od poze, spontanost i izbor težeg puta jesu neka vrsta Desničinog spiritus movensa:

Ima jedno svojstvo kod velikih pisaca (...) taj momenat trajnosti [je] možda ono najbitnije što sačinjava istinski velikog pisca. (...) Eto, za ljubav te „trajnosti“ pisac treba da ima hrabrosti da se samodisciplinirano odrekne mnogo efekata, mnogo momentalno veoma zahvalnih narcisoidnih, samodopadnih, površno blistavih momenata i gracioznosti u kojima blista piščeva empirijska ličnost i nalaze njegova empirijska zadovoljenja. ${ }^{34}$

Desničin izbor da, uprkos svim teškoćama, ostane veran sopstvenim imperativima i ne podvrgava se nametnutim očekivanjima, bili su odraz umetničkog creda, što je uzrokovalo izopštenost iz javnog i kulturnog života - i tamo i ovde.

Bez obzira na istrajnost i sleđenje ličnih načela, Desnica je svoj položaj osećao kao trpilački. Duhovito je komentarisao genetsko nasleđe i vezu sa nadaleko čuvenim pretkom Stojanom Jankovićem: „Ne znam. Osim, ako se Stojanova aktivna hrabrost u meni pretvorila, ili degenerirala, u gotovo beskonačnu moć 'dolgoterplenja.". 35 Usled neprijatnosti i čestih nesporazuma, žalio je zbog nerealizovane muzičke karijere, verujući da bi ga zasigurno poštedela mnogih polemika i nerazumevanja:

Bio sam jedno vrijeme u dilemi da li da se više orijentišem muzici ili literaturi. Vjerovatno bih u muzici postigao manje, ili još manje, nego u literaturi. Pa ipak, često zažalim što nisam pošao tim putem. Muzika ima jednu golemu, prevashodnu prednost nad riječju: muzička rečenica nije ukleto osuđena da pored svog estetskog ima i jedno logičko, doslovno, značenje. Kakve li utjehe i smirenja u tome i koliko li izbjegnutih nesporazuma! ${ }^{36}$

Ostajući „van generacijskih klišea i svrstavanja“, ${ }^{37}$ ne priklanjajući se taborima i ne dozvoljavajući da bude etiketiran i prisvojen, rečnikom Crnjanskog kazano - ispunio je svoju sudbinu.

(...) Desnica je bio nedovoljno naš, ali ni potpuno njihov! A, u stvari, bilo je premalo razloga da ga bilo ko i prisvoji i, istovremeno, odriče pravo onom drugom da to čini. On jednako izmiče i jednima i drugima, odavno izašavši iz ovdašnjih okvira, nikad samlji i nikad više svoj. Tek odabran i - za odabrane! (...) Marginalizacija njegovog dela pravdana je brojnim (jednako neuverljivim) razlozima. Jednima je bio dekadent, reakcionar i, u krajnjoj liniji, prikriveni srpski nacionalista koji podriva hrvatski jezički standard, na mala vrata uvodeći ekavizme, drugima je, opet, sve to preterani esteticizam koji se „u svemu oslanja na Kročea“, a, i da se ne lažemo, odveć vuče na hrvaštinu. Preostalo mu je da bude ono što jeste - svetski pisac. ${ }^{38}$

\footnotetext{
$\overline{34}$ [Marino Zurl], „Posjeta. Uz 50-godišnjicu života književnika Vladana Desnice“, u: V. Desnica, Hotimično iskustvo, knj. 1., 34 .

35 „Razgovor na Radio Beogradu 22. III 1961.“, u: V. DesniCa, Djelo nastaje dalje od pisaćeg stola (prir. Jovan Radulović), Beograd 2005., 84.

36 [Ivanka Bešević], „Između muzike i literature. Razgovor s književnikom Vladanom Desnicom“, u. V. DesnicA, Hotimično iskustvo, knj. 1., 81.

37 V. Desnica, Djelo nastaje dalje od pisaćeg stola, 10.

38 Mirko Demić, „Čiji je Desnica?“, Koraci, 11-12/2005., 5-7.
} 
Govoriti o Vladanu Desnici trebalo bi da znači - govoriti o umetniku klasiku, o svojevrsnom domaćem međuknjiževnom piscu ${ }^{39}$ svetskog ranga, koji nadilazi svaki pokušaj svrstavanja. O tome na najbolji način svedoče piščeve reči:

Svrha umjetnosti je nešto, bar naoko, sasvim malo i jednostavno; objektivizacija raznih (...) ljudskih realiteta (kako tuđih, tako i vlastitih, piščevih), podrazumijevajući pod realnošću i realnost ljudskih snova i ognjica; i halucinacija itd. (...) kako umjetnost ne znači poučiti (to je didaktička estetika), ne znači osuditi (to je moralna ili politička estetika), već samo: upoznati, spoznati, proniknuti. ${ }^{40}$

Duboko humanom koncepcijom, koja počiva na ideji da je „očovječenje čovjeka“ zapravo „krajnja svrha i svaki dublji smisao književne djelatnosti“, prožeto je celokupno Desničino delo. Svaki drugačije usmeren diskurs, koji pokušava da prenebregne tu činjenicu, preti da isklizne u neumetničku i neknjiževnu proizvoljnost.

\section{$\cos$}

\section{ON FRIENDSHIP AND OTHER THINGS}

The correspondence between Vladan Desnica, his children Uroš and Nataša Desnica, and Dragan M. Jeremić is a testimony to the friendship between these two writers, but what is more, it reveals the part Jeremić played in the reception of Desnica's writing in Serbia. In fact, the letters were an incentive to examine Desnica's position within Croatian and Serbian literature as a writer with a dual identity. In order to fully understand the artist's position on the cultural territory of Croatia and Serbia, we must point out the importance of the context in which he lived and worked. Therefore, a part of this paper is dedicated to reviewing the so-called external factors that evidently played a decisive role in Vladan Desnica's writing. We might even go so far as to say that these non-artistic, non-literary factors determined his fate as a writer. Consistent in his resistance to conforming to imposed rules and patterns, and refusing to "pick a side", Desnica was perceived as a threat to the further development of literature and targeted for removal from the literary scene. The defenders of the "dogma" of the time made sure to banish him from cultural public life. Desnica's polemic legacy speaks of the circumstances he worked in, the numerous attacks he endured and the criticisms he faced (such as questioning of the moral purity of his heroes, the insistence on a precise determination of time and place that his novels are set in, the scrutiny of his use of particular words(...). Among other things, his correspondence with Dragan M. Jeremić reveals certain facts which speak of the general animosity towards Desnica during the 1950s and the 1960s. We would like to point out that, in addition to shedding a light on the treatment of one of the most notable Yugoslav writers by the public, these letters provide an opportunity to touch upon the subject of interculturalism. Identity is, so to speak, an almost fashionable issue today. Every day we are inundated with discussions (grounded in numerous theoretical outlooks) about different forms of identity. The concept of interculturality has therefore gained in popularity and frequency. Still,

39 Ovom prilikom podsetićemo da na kraju Proljeća Ivana Galeba izlaze u Sarajevu, a kritička recepcija ukazuje i na dubok trag Desničine književnosti i u drugim jugoslovenskim sredinama, posebno u Sloveniji.

40 [Grozdana Olujić Lešić], „Upoznati, spoznati, proniknuti... Razgovor s Vladanom Desnicom“, u: V. DESNICA, Hotimično iskustvo, knj. 1., 55-56. 
the paper questions whether it is justified to use that term when examining the work of Vladan Desnica. Keeping in mind that the construction of identities is always ideologically charged, it seems inappropriate to apply contemporary frameworks/standards/terms when studying a period that lacked such an apparatus.

Key words: Vladan Desnica, Dragan M. Jeremić, correspondence, identity, interculturalism

\section{cos}

\section{Izvori}

Arhiv SANU, neobrađena građa

\section{Literatura}

Antun BARAC, Jugoslavenska književnost, Zagreb 1963.

Tihomir Brajović, „Nekoliko reči o komparativnom identitetu savremene srpske književnosti“, MSC, 40/2001., br. 2, 327-339.

Mirko Demić, „Čiji je Desnica“, Koraci, 11-12/2005., 5-7.

Vladan Desnica, Djelo nastaje dalje od pisaćeg stola (prir. Jovan Radulović), Beograd 2005.

Vladan Desnica, Hotimično iskustvo - diskurzivna proza Vladana Desnice, knj. 1. (prir. Dušan Marinković), Zagreb 2006.

Vladan Desnica, Hotimično iskustvo - diskurzivna proza Vladana Desnice, knj. 2. (prir. Dušan Marinković), Zagreb 2006.

Vladan Desnica, Progutane polemike (prir. Jovan Radulović), Beograd 2001.

Vladan Desnica, „Tri pisma Veljku Petroviću“, Književna istorija, XLVII/2015., br. 156, 169-173.

Državljani i državljanstvo (prir. Džon Šo i Igor Štiks), Beograd 2012.

Dragan M. Jeremić, Prsti nevernog Tome, Beograd 1965.

Dragan M. Jeremić, „Za očovječenje čovjeka - govor održan prilikom ispraćaja posmrtnih ostataka Vladana Desnice“, Telegram (Zagreb), VIII, br. 358, 10. 3. 1967., 10.

Leksikon savremene kulture. Teme i teorije, oblici i institucije od 1945. do danas (prir. Ralf Šnel), Beograd 2008.

Radovan Popović, „Preplitanja proleća i smrti. Fragmenti za biografiju Vladana Desnice“, Književni magazin, V/2005. (avgust), br. 50, 58-61.

Aleksandar Tıšma, Pre mita, Banjaluka 1989. 


\section{Prilozi}

\section{Dopisnice i pisma Vladana Desnice \\ Draganu M. Jeremiću}

I.

[Zagreb 18. 10. 1962.]

drug

Dragan Jeremić

književnik

Ž E L E Z N I K / kod Beograda

Železnička stanica

Zagreb, 18. oktobra 1962.

Dragi Jeremiću,

Eto, vratio sam se i ja s ljetovanja. Hvala Vam na kartama iz septembra. Malo zatim stigla je i akontacija. Nego, sad odjednom opet prijatno iznenađenje: neki dan vidio sam u „Politici“ veliki oglas nove serije, ali u njoj nije „Galeb“ već Rankove „Ruke“. Ta stalno je govoreno i potvrđivano da će moja knjiga izići u novembru, a sad me eto izboksiraše napolje! To me je vrlo neprijatno iznenadilo, i mnogo mi pomrsilo planove. Lijepo Vas molim, govorite s drugom Ilićem (možete razumjeti, nije mi ugodno da mu ja to pišem) i nastojte svakako da se mojoj knjizi vrati red koji joj je bio dan te da iziđe u novembarskoj seriji.

Inače ništa novo. Prevodim jednu dozlaboga dosadnu knjigu dječijih priča. Kad navratite u Zagreb, svakako se javite. Čujem da je JDP (poslije samih dvanaestak predstava) skinuo „Ljestve" s programa - ne znam da li je tačno. Hajde, i to je neka vrst rekorda!

Srdačno Vas pozdravljam

Vaš Vladan Desnica

II.

Mr.

Dragan Jeremić

Železnik (kod Beograda)

(Žel. stanica)

Mnogo sreće i uspjeha u 1963.

Želi Vam 


\section{III.}

[Zagreb 5. V 63. / Železnik, 7. V 63.]

drug

Dragan Jeremić

književnik

ŽELEZNIK kod Beograda

(Žel. stanica)

\section{Dragi Dragane,}

Tek prije nekoliko dana vratio sam se s tromjesečnog boravka u Dalmaciji (na selu), a uskoro se opet tamo spremam. Ako po budžacima redakcije imate još nekoliko brojeva „Savremenika“ (i defektnih) u kojima su štampane „Ljestve“, molim Vas pošaljite mi ih, uvijek mi trebaju. Što radite i kamo i kada namjeravate ljetos?

Srdačno Vas pozdravljam Vladan Desnica

\section{IV.}

[Zagreb, 24. IX 63. / Železnik, 26. IX 63.]

drug

Dragan Jeremić

Železnik kod Beograda

Železnička stanica

Zgb. 24. 9.

Dragi Jeremiću,

Mislim da ću u četvrtak predveče, 26. o. m., stići u Beograd na 2 dana. Otsjest ću u Savezu. Rado bih Vas vidio, javite se, a i ja ću Vas nastojati da pronađem. (Ako bude kakav dobar koncert, ili predstava, može i to!)

(Ako ste bili u Zadru a niste me potražili, biti će mi krivo.)

Srdačno Vaš Vladan Desnica 


\section{V.}

\section{Drug}

Dragan Jeremić

- književnik -

ŽELEZNIK (kod Beograda)

Železnička stanica

Dragi moj Jeremiću,

Već dulje vremena namjeravam da Vam opširnije pišem, ali me drži nekakva gripica. Zato sada samo nekoliko riječi, toliko da Vam srdačno zaželim mnogo zadovoljstva i uspjeha u Novoj, 1964. godini.

Ako navratite u Zagreb, svakako se javite.

Vaš Vladan Desnica

\section{VI.}

[Zadar, 11. 5. 1964., 12h]

drug

Dragan Jeremić

Železnik kod Beograda

(Žel. stanica)

\section{VLADAN DESNICA I PORODICA}

Toplo zahvaljuju na saučešću.

[У писму је ВАадан Аесница приможио и умрлицу поводом смрти мајке Фани:

$+$

Rodbini i prijateljima javljamo tužnu vijest da je u četvrtak, 26. Marta umrla naša majka, svekrva, baka FANNY ud. Dr-a Uroša DESNICE rođ. Luković

Sahrana će se izvršiti na Gradskom groblju u subotu 28. o. mj. u 15.30 sati. Zadar, 27. marta 1964.

Riječka ul. 15
VLADAN NATAŠA KSENIJA OLGA, JELENA, NATAŠA, UROŠ sin kći snaha unučad

(Specijalni autobus kreće u 15 sati od mosta na poluotoku.)] 


\section{VII.}

[Zagreb, 3. X 64.]

drug

Dragan Jeremić

književnik

Beograd

Knez Mihajlova 40/I

Filozofski seminar

Zagreb, 3. oktobra 1964.

Kraševa 14

Dragi Jeremiću,

Primio sam i drugu polovicu honorara od „Branka Đonovića“ za novo izdanje „Galeba“, iz čega zaključujem da bi knjiga uskoro imala da izađe. Tim toplije Vam stavljam na srce ono za šta sam Vas i usmeno zamolio, t. j. 1) da na jednom bijelom listu bude posveta: Kseniji, 2) da svakom primjerku prilože listić sa glasovima kritike kao što su učinili i kod I. izdanja, 3) da mi pošalju reviziju jer se tekst kroz preštampavanje natrunio grdnim greškama. Kako štampanje listića ide na moj račun, ako nisu odbili od honorara, neka mi jave koliko to iznosi pa ću odmah doznačiti poštom. Mnogo Vam sve troje preporučam.

Kad naiđete u Zagreb svakako se javite, u Titogradu smo imali malo vremena za razgovor. Srdačan pozdrav, Vaš

Vladan Desnica

\section{VIII.}

[Jelsa, 24. VII 65.17]

drug

Dragan M. Jeremić

Železnik (kod Beograda)

Železnička stanica

Jelsa, 24. VII

Dragi Jeremiću,

Sa zadovoljstvom ću primiti Vašu knjigu. Adresirajte: V. D. Jelsa na Hvaru. Tu sam do 5. VIII, a onda u Zadru (Riječka 15/I) valjda do pred kraj augusta. Ne čudite se što u Zgb. još nije izišao nikakav prikaz. Tako je obično.

Srdačno Vas pozdravljam

Vaš Vladan Desnica 


\section{DODATAK: PISMA KĆERKE NATAŠE I SINA UROŠA Draganu M. Jeremiću}

I.

Pismo Nataše Desnice

[Zagreb, 28-IV 1967. 15-16]

Gospodin

Dragan M. Jeremić

Dimitrija Tucovića 24

BEOGRAD

Nataša Desnica Zagreb, 27. IV 1967.

Kraševa 14

Zagreb

Poštovani i dragi gospodine Jeremiću,

Toplo Vam zahvaljujem, i u ime svoje braće, što uz svu svoju prezauzetost nalazite vremena da s nama održavate kontakt i što želite da sačuvate svoje lijepe osjećaje za našeg tatu sad kad više nije među nama. Čudno nam je što ste mogli i pomisliti da Uroš ili bilo tko od nas ne zna za Vas, jednog od rijetkih vjernih prijatelja našeg oca, koji je Vas mnogo volio i cijenio. Razumijemo Vaše žaljenje što niste stigli da porazgovarate s njim o svemu što ste željeli, jer se i mi tako osjećamo i žalimo za mnogočim što je trebalo da od njega čujemo i primimo, i što smo očekivali kao da nam pripada, ne želeći da vjerujemo da je kraj već blizu, a sad nam je, eto, uskraćeno.

Neobično nam je drago i utješno da namjeravate svoje poznavanje njegovog lika i djela pružiti javnosti, jer smo uvjereni da nitko ne bi to bolje od Vas uradio. Baš se osjećala potreba za jednom dobrom monografijom, koja će i buduće proučavanje tatinog djela upraviti u dobrom smjeru, jer do sada su mnogi pisali sa izrazitim nedostatkom sluha za njegove vrednote, čak i kad je to bilo dobronamjerno. Naravno, da ćemo Vam vrlo rado pomoći u svemu što stoji do nas. Drago nam je da ćete doći u Zagreb ovog ljeta, i nadamo se da ćete puno više Vi pomoći nama u delikatnom problemu književne ostavštine, koji se nadamo riješiti našim poznavanjem njegovih želja i namjera, i Vašom kompetencijom i kriterijem u književnosti. Možda bi bilo zanimljivo za Vas, da dođete na neko vrijeme u Islam, gdje mnogo toga podsjeća na tatu i pomaže da se osjeti jedan ambijent i jedna vrst senzibilnosti.

Zahvaljujemo Vam što ste nas obavijestili o održanim komemoracijama. Svakako ćemo nabaviti majski broj Letopisa s Vašim člankom. Moramo Vam reći da je Vaš govor napravio veliki utisak, i da je po mišljenju ne samo nas bio daleko najvredniji od svih koji su održani u Zagrebu i Islamu.

Nadamo se da ste već sasvim dobro sa zdravljem. Molimo Vas da prenesete naše lijepe pozdrave vašoj gospođi i djevojčici. Vama još jednom srdačno zahvaljujemo na svemu.

Nataša Desnica 


\section{II.}

Pismo Uroša Desnice

[Zagreb, 15. V 72. 19h]

Drug

Dragan M. Jeremić

„Književne novine“

Francuska 7

11000 Beograd

Zagreb, 14. V 1972.

Dragi druže Jeremiću,

Najprije da Vam najsrdačnije čestitam na izboru za predsjednika U. K. Srbije, iako znam da će Vam ta obaveza oduzimati dosta vremena, kojeg, sigurno ni inače nemate dovoljno.

Pišem Vam, jer bih Vam želio javiti o jednoj novosti a ujedno zamoliti za savjet i informaciju. Obratili su mi se iz zagrebačke „Prosvjete“ budući da bi željeli izdati sabrana djela mog oca (u 5 knjiga, 3000 kompleta i to već ove jeseni). Ni sa jednom knjigom nemamo nikakvih obaveza prema izdavačima, međutim ne znam kako stvari stoje sa „Athanatikom“, za koji bi oni, razumljivo, također želili da uđe u sabrana djela. Ja sam ih obavijestio da sam ga predao Vama sa nadom i željom da ćete ga Vi redigirati i „dovršiti“, te da ne znam da li ste šta o njemu već detaljnije govorili sa SKZ - ne bih želio da prema njima ispadne nezgodno (tim prije što bi mi bilo drago da se „Athanatik“ pojavi u izdanju SKZ). Tako će se direktor „Prosvjete“ uskoro obratiti Vama (i eventualno SKZ, ako treba).

Žao mi je što Vas u vezi s ovim moram zagnjaviti za jednu uslugu, odnosno informaciju, ali ne poznam nikog koga bi mogao direktno pitati. Ja sam se nadao da će pitanje honorara, kao obično do sada, ići više manje automatski, tj. da postoje neki ustaljeni uzusi za određene kategorije pisaca, ali nažalost nije ispalo tako. Izdavač inzistira da se honorar veže uz postotak od cijene kompleta. Mi međutim nemamo nikakvog iskustva s takvim načinom honoriranja (a ponuda mi se ne čini baš povoljna), pa bih Vam bio jako zahvalan ako biste mi mogli pružiti koju informaciju o tome. Čuo sam da se takav način plaćanja udomaćuje u Beogradu, a kod Vas je izdano i znatno više pisaca u sabranim djelima nego ovdje, a vjerujem da općenito vrijede druga pravila [za] sabrana djela nego za pojedinu knjigu. Nadam se da to nisu izdavačke tajne. Isto tako volio bih čuti, ako možda znate ili možete na jednostavan način saznati, na koliko obično vremena izdavači blokiraju pravo autora da sklapa ugovore sa drugim izdavačima. (Traže nam 5 godina, što mi se čini jako dugo). Kad Vam već uzimam vrijeme ovim pitanjima (na čemu se još jedamput izvinjavam), želio bih Vam, kao prijatelju, reći kako raspolažemo s honorarima našeg oca. Sve do sada primljene honorare u ovih 5 godina (a nadamo se da ćemo to moći i ubuduće) uložili smo u obnovu kompleksa u Islamu Grčkom („dvori Jankovića Stojana“. Do sada smo uspjeli učvrstiti i napraviti propali krov porodične kapele u kojoj je tata sahranjen inače jedna od starijih crkvica u Dalmaciji (XII st.), te dio krovova na glavnim zgradama. Sve skupa donkihotski posao jer čovjeku uspije popraviti otprilike na jednom dijelu onoliko koliko se na drugom sruši, ali - borimo se. Ipak bismo želili održati zdanje bar u takvom stanju, da 
se jednom, kad društvo bude imalo više materijalnih mogućnosti i dobre volje za temeljitiju restauraciju i uređenje za muzej, još bude imalo šta popravljati.

Nadam se da ste dobro sa zdravljem. Najljepši pozdravi Vama i Vašoj obitelji Vaš

Uroš Desnica

P. S. Šaljem Vam broj mojeg žiro računa, što ste me odavno bili pitali: 301-620-1001-2320 120-390.

\section{BELEŠKE UZ PISMA I DOPISNICE UPUĆENE Draganu M. Jeremiću}

Dragan M. Jeremić (rođen 1925. u Brđanima kod Gornjeg Milanovca - umro u Beogradu 1986.) filozof, estetičar, književni kritičar, urednik. Najpoznatiji je po polemici sa Danilom Kišom, dok je vrednost njegovog dela u srpskoj kulturi skoro potpuno marginalizovana.

Sačuvane dopisnice i pisma razmenjivana sa Vladanom Desnicom nalaze se u „zatvorenoj“ zaostavštini u Rukopisnom odeljenju SANU, a dobila sam ih zahvaljujući dobroti Radovana Popovića, najznačajnijeg biografa srpske književnosti i najboljeg poznavaoca rukopisnih arhiva na prostoru bivše Jugoslavije.

Pisma i dopisnice otkrivaju ulogu Dragana Jeremića u recepciji Desničinog dela u Beogradu. Ono što je najvažnije odnosi se na nova izdanja Proljeća Ivana Galeba (sa predgovorom Dragana Jeremića), objavljena u biblioteci „Omiljeni pisci“, u štamparijama „Branko Đonović“ (1962. i 1963.) i „Savremena administracija“ (1964.), uključujući i dramu Ljestve Jakovljeve. Drama u dva čina (objavljena u časopisu Savremenik, 2/1961., 117-139 i 3/1961., 274-307).

Što se Jeremićevog kritičkog vrednovanja Desničinog dela tiče, možemo reći da je on bio jedan od najposvećenijih tumača njegovog romaneskno-novelističkog opusa, o čemu najbolje svedoče sledeći tekstovi:

- „Roman ideja: prvi put. (Vladan Desnica: Proljeća Ivana Galeba, Sarajevo, 'Svjetlost' 1957)“, NIN, br. 365, 29. 12. 1957.

- „Vladan Desnica ili intelektualna poezija“, Savremenik, 6/1958., 641-659.

- „Izabrane priče Vladana Desnice. (Fratar sa zelenom bradom, Zagreb, 'Mladost', 1959)“, Književne novine, br. 101, 11. 9. 1959.

- „Vladan Desnica. (Predgovor)“, u: Isti, Proljeća Ivana Galeba, Beograd 1962., 5-10 (Biblioteka „Knjiga za svakoga. Omiljeni pisci“, knj. 16); isto, u: Isti, Proljeća Ivana Galeba, Beograd 1963., 5-11 (Biblioteka „Knjiga za svakoga. Omiljeni pisci“, knj. 16); isto, u: Isti, Proljeća Ivana Galeba, Beograd 1964., 5-10 (Biblioteka „Knjiga za svakoga. Omiljeni pisci“" knj. 16)

- „Vladan Desnica“, u: Dragan M. Jeremić, Prsti nevernog Tome, Beograd 1965., 152-176.

- „Za očovječenje čovjeka - govor održan prilikom ispraćaja posmrtnih ostataka Vladana Desnice iz Zagreba u Islam Grčki“, Telegram (Zagreb), VIII, br. 358, 10. 3. 1967.

• „Vladan Desnica“, Letopis Matice srpske, knj. 399, CXLIII/1967., br. 3, 467-475. 
Koliko je Vladan Desnica poštovao i uvažavao Dragana Jeremića slikovito nam govori jedan detalj: u „Popisu kućne biblioteke Vladana Desnice“, koji su sačinili sin Uroš Desnica i profesor Dušan Marinković (objavljen kao prilog u knjizi Hotimično iskustvo - diskurzivna proza Vladana Desnice, priredio i redigovao Dušan Marinković, Zagreb 2006., 277), otkrivamo podatak da je Desnica u maloj polici uz svoj radni sto čuvao knjigu Dragana M. Jeremića Prsti nevernog Tome.

Kao zaključak ovoj belešci citiraćemo završni pasus iz Jeremićevog teksta „Vladan Desnica“, koji je objavljen kao „In memoriam“ u martovskom broju Letopisa Matice srpske:

„Svojom književnom pojavom Vladan Desnica, kao Srbin koji je stvarao u okviru hrvatske književnosti, predstavlja i jednu od duhovnih karika između srpskog i hrvatskog naroda i time je postigao još jednu sintezu od onih mnogih koje njegovo delo čine jednim od najznačajnijih dela u savremenim jugoslovenskim književnostima." 